\title{
Evaluation the effects of different levels of Echinacea purpurea extract on the immunity responses, biochemical and hematological indices and disease resistance against Streptococcus iniae in rainbow trout (Oncorhynchus mykiss)
}

\author{
M Sharif Rohani ${ }^{1}$, R Pourgholam ${ }^{2}$, M Haghighi ${ }^{3}$ \\ ${ }^{1}$ Iranian Fisheries Science Research Institute (IFSRI), Agriculture Research, Education and Extension \\ Organization (AREEO), Tehran-Iran \\ ${ }^{2}$ Iranian Fisheries Science Research Institute (IFSRI), Caspian Sea Ecology research Center, Agriculture \\ Research, Education and Extension Organization (AREEO), Sary-Iran \\ ${ }^{3}$ Iranian Fisheries Science Research Institute (IFSRI), Coldwater Fishes Research Center (CFRC), Agriculture \\ Research, Education and Extension Organization (AREEO), Tonekabon-Iran
}

Received: April $2015 \quad$ Accepted: August 2015

\begin{abstract}
240 rainbow trout fingerlings weighting 16 gram were randomly allocated into three treatment groups including 0.5, 1.0and $1.5 \mathrm{gr} / \mathrm{kg}$ of Echinacea purpurea extract in food, and a control group (without EPE in food), each intriplicates for 60 days. At sampling times, some of hematological and biochemical parameters including $\mathrm{C}_{3}$ and $\mathrm{C}_{4}$ complements, oxygen free radicals, lysozyme activity, and other hemathological parameters were analyzed. Also, at the end of the experiment, fishes challenged with Streptococcus iniae and the mortality was analyzed.

Correspondence M Sharif Rohani, Iranian Fisheries Science Research Institute (IFSRI), Agriculture Research, Education and Extension Organization (AREEO), TehranIran (e-mail: mostafasharif@yahoo.com)
\end{abstract}

However, there were no significant differences in $\mathrm{C}_{4}$, total immunoglobulin, lymphocyte and monocyte $(p>0.05)$. The amount of glucose, serum total protein and albumin decreased at the end of the experiment significantly $(\mathrm{p}<0.05)$. In addition, the results showed that mortality percentage in Echinacea treatment group with $1.5 \mathrm{gr} / \mathrm{kg}$ concentration was significantly lower than other treatment groups $(\mathrm{p}<0.05)$. In conclusion the results have shown that Echinacea extract had the positive effect on immunity responses of rainbow trout especially in higher concentration $(1.5 \mathrm{gr} / \mathrm{kg})$. Also, adding Echinacea extract in rainbow trout diet increased the resistance of rainbow trout against $S$. iniae.

Keywords: bacterial challenge, hematology, immunology, Echinacea purpurea 


\section{Introduction}

Rainbow trout (Oncorhynchus mykiss) is the most preferred coldwater species in aquaculture industry of Iran. Achieving sustainable development in rainbow trout culture, to maintain the health status of this fish is of major importance. Fish pathogenic organisms are a serious threat to economic viability of any aquaculture practice. Currently, the use of antibiotics for the prophylaxis and treatment of diseases leading to the development of antibiotic resistant bacterial strains, accumulation of residue in cultured fish and environmental problems. Therefore, a new approach to immunotherapy is actively used to prevent ortreat fish diseases. In this regard, extensive research has been carried out to test various immunostimulants including medicinal plants which they have found to be effective in fish. It has beenfound that use of medicinal herbs in fish diets enhance the immune system against infections with various bacteria like $S$. iniae, especially (Leal, Freire, Carvalho, Oliveira \& Figueiredo 2008; Ahamad, El Mesallamy, Samir \& Zshran2011; Maqsood, Singh, Samoon \& Munir 2011; Subeena Begum \& Navaraj 2012).

$$
\text { Echinacea belonging to family }
$$
echinaceadea is a grass form planet with 60$150 \mathrm{~cm}$ high. Three species of this planet (Echinacea purpurea, E. pallida, E. angustifolia) have medical property. Underground rhizomes and aerial organs of this planet mostly used (Soudi, Hashemi, Zavaran Hosseini, Ghaemi \& Asghari Jafarabadi 2007).
Some of the known most important ingredients of E. purpurea extract (EPE) were caryophyllenB, 8-pentadecadiene, germacrene-D and propyl paraben (Morrazoni, Cristoni, Di Pierro, Avanzini, Ravarino, Stornello, Zucca \& Musso 2005; Xu, Xia, Wang \& Wang 2008; Dahui, Wang, Zaigui \& Yunhua 2011). Also Echinacea had the immunostimulant and anti inflammation effects especially against bacterial and viral disease (Melchart, Walther, Linde, Brandmier \& Lersch1998; Galina, Yin, Ardo \& Jeney 2009; Dahui et al., 2011). Furthermore, Echinacea extract increased humeral and cellular resistance in vertebrates (Stimpel, Proksch, Wagner \& Lohman1984). The aim of the present study was to evaluate the effects of different levels of $E$. purpurea extract (EPE) on various parameters of non-specific immunity responses including respiratory burst activity, phagocytic activity of blood leukocytes, serum lysozyme activity, total plasma protein level and some of haematological indices in rainbow trout (Oncorhynchus mykiss) to develop alternative drug for the prevention or the treatment of diseases especially Streptococcus iniae in aquaculture.

\section{Material and Methods}

\section{Preparation of Echinacea purpurea extract (EPE)}

The plant of Echinacea was procured from Medicinal Plants Production Cooperation of Havin and plant species was identified and confirmed by a botanist. The leaves were separately shade-dried for 10 day till weight 
constancy was achieved. The sample was powdered in an electric blender. The extract was prepared with the standard method of percolation (Morrazoni et al., 2005). To do this, chopped dried plant leaves in $75 \%$ ethanol were percolated for 72 hours. Then, the slurry was filtered with Whattman No. 1 filter paper and centrifuged for $5 \mathrm{~min}$ at $5000 \mathrm{rpm}$. The filtrate obtained from ethanol using a rotary device, the excess solvent was separated from the extract. These crude extract was stored at $4^{\circ} \mathrm{C}$ until use. The extract added to formulated fish diet in three different doses $(0.5,1.0$ and $1.5 \mathrm{gr} / \mathrm{kg}$ food). The food was FFT-1 produced by an Iranian fish food factory (Mazandaran Fish Food Co, Mazandaran, Iran). The EPE added to diet using canola oil for coating in three different concentrations.

\section{Fish, experimental conditions and sampling}

240 rainbow trout weighing 16 gram were used. All experiments were carried out in 12 fiberglass tanks with water flow. The fish were kept at controlled water temperature of $15 \pm 1^{\circ} \mathrm{C}$. After 2 weeks adaptation, fish were randomly allotted in four groups including three experimental groups anda control group, in triplicate was maintained in 12 concrete ponds each containing 20 fish. Each group was hand-fed once a day with diet medicated different doses of $E$. purpurea extract (EPE) for 60days. In days of 30 and 60 after feeding, 9 fish from each replicate sampled and bleed. Half collected in serological tubes containing a pinch of lithium heparin powder, shaken gently and kept at $4^{\circ} \mathrm{C}$ to test hematological parameters. Other half collected in tubes without of anticoagulant and allowed to clot at $4^{\circ} \mathrm{C}$ for $2 \mathrm{hrs}$ to test serological parameters. The clot was the spun down at 2000 rpm for $10 \mathrm{~min}$ to separate the serum. The serum collected by micropipette and was stored in sterile Eppendorf tubes at $-20^{\circ} \mathrm{C}$ until used for assay.

\section{Immunological assay}

$\mathrm{C}_{3} \& \mathrm{C}_{4}$ complements and total Immunoglobulin assayed by a commercial kit (Pars Azmoon, Iran) and authorizer (Eurolyser, Belgium) based on method described by (Shahsavani, Mohri \& Gholipour Kanani2010) and (Johnson, Rohlfs \& Silverman1999).

\section{Serum Lysozyme and Respiratory burst activity}

Respiratory burst activity was quantified by method described by Matheus(1990) using a luminoscanascent device (Thermo, Finland). Also an assay based on the method described by Ellis (1990) used to determine lysozyme activity.

\section{Biochemical analysis}

Serum total protein, glucose and albumin assayed by a commercial kit (pars Azmoon, Iran) and authorizer machine based on the method described by Whicher (1996).

\section{White Blood Cell (WBC)}


The differential leukocytes count was carried out using blood smears stained with Wright-Giemsa. The percentage composition of leukocytes was determined based on their identification characters listed by Ivanava (1983).

\section{Bacterial challenge}

Bacteria separated from the fishes suspiciously tainted to Streptocuccos is identified by bacteria culture and cellular methods (Buller 2004; Austin \& Austin 2007). Afterwards final identification was done. In order to challenge fishes with bacteria, $0.1 \mathrm{ml}$ of bacteria suspension adjusted by McFarlaine tube No.1, injected in fishes belly. Then fishes analyzed for 14 days (Rodas, Angulo, Cruz \& Garcia (2002). After the disease appearance kidney, liver and heart of fishes sampled and cultured in blood agar using Austin \& Austin method (2007) and finally presence or in presence of colonies determined.

\section{Statistical analysis}

All results for each parameter measured were expressed as means \pm standard deviation, and were compared at each time point using student's t-test for independent data. Significant differences between experimental groups were expressed at a significance level of $\mathrm{P}<0.05$. All analyses were carried out on 9 fish per group.

\section{Results}

Immunological results are shown in table 1. The results have shown that there was no significant differences between treatment groups in total immunoglobulin in days of 30 and 60 (p>0.05). Also there was no significant differences between treatment groups in $\mathrm{C}_{3}$ concentration, but $\mathrm{C}_{3}$ concentration in treatment groups comparing to control, significantly increased $(\mathrm{p}<0.05)$. Nonetheless there was no significant differences between treatment groups in $\mathrm{C}_{4}$, total protein, albumin and glucose concentrations in days of 30 and 60 ( $>>0.05)$. But, the other parameters including oxygen free radicals and lysozyme significantly changed in treatment groups. The results are shown that oxygen free radicals and lysozyme concentration in fishes feed with $1.5 \mathrm{gr} / \mathrm{kg}$ of EPE were significantly higher than the other groups in days of 30and 60 ( $\mathrm{p}<0.05)$. Hematological parameters results are shown in table 2. The results have shown that WBC in treatment groups feed with 1 and1.5 gr $/ \mathrm{kg}$ of EPE, was significantly higher than 0.5 treatment group and control group in days of 30 and $60(\mathrm{p}<0.05)$. Also, there was significant differences between treatment groups and control group in neutrophils percentage days of 30 and $60(\mathrm{p}<0.05)$. However, there were no significant differences between control and treatment groups in monocyte and lymphocyte percentage in days of 30 and 60 (p>0.05). 
Table 1 Immunological and biochemical results in fishes feed by Echinacea purpurea extract $(\mathrm{EPE})($ mean $\pm \mathrm{SD})$

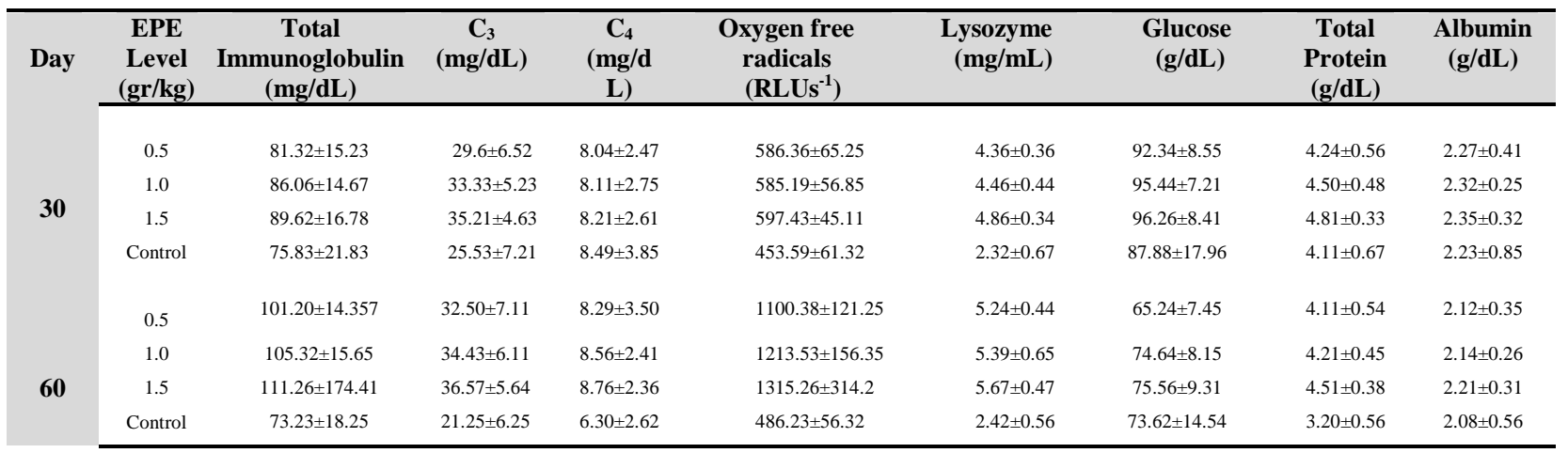

The results are shown that oxygen free radicals and lysozyme concentration in fishes feed with $1.5 \mathrm{gr} / \mathrm{kg}$ of EPE were significantly higher than the other groups in days of 30 and $60(\mathrm{p}<0.05)$. Hematological parameters results are shown in table 2. The results have shown that WBC in treatment groups feed with 1 and $1.5 \mathrm{gr} / \mathrm{kg}$ of EPE, was significantly higher than 0.5 treatment group and control group in days of 30 and 60 $(\mathrm{p}<0.05)$. Also, there was significant differences between treatment groups and control group in neutrophils percentage days of 30 and 60 $(\mathrm{p}<0.05)$. However, there were no significant differences between control and treatment groups in monocyte and lymphocyte percentage indays of 30 and 60 (p>0.05).

Table 3 shows the survival results of bacterial challenge. The results have shown that there were significant differences between treatment groups and control group in survival rate after the bacterial challenge.

Table 2 Hematological parameters results (mean \pm SD)

\begin{tabular}{|c|c|c|c|c|c|}
\hline Day & $\begin{array}{c}\text { EPE } \\
\text { Level } \\
\text { (gr/kg) }\end{array}$ & $\begin{array}{l}\text { WBC } \\
\left(\times 10^{3}\right)\end{array}$ & $\begin{array}{c}\text { Neutrophil } \\
(\%)\end{array}$ & $\begin{array}{c}\text { Monocyte } \\
(\%)\end{array}$ & $\begin{array}{c}\text { Lymphocyte } \\
(\%)\end{array}$ \\
\hline 30 & $\begin{array}{c}0.5 \\
1.0 \\
1.5 \\
\text { Control }\end{array}$ & $\begin{array}{c}10.50 \pm 0.35 \\
10.8 \pm 0.76 \\
10.50 \pm 0.83 \\
9.70 \pm 0.73\end{array}$ & $\begin{array}{l}2.32 \pm 0.97 \\
2.35 \pm 0.78 \\
2.21 \pm 0.70 \\
1.44 \pm 0.53\end{array}$ & $\begin{array}{l}1.56 \pm 0.12 \\
1.71 \pm 0.13 \\
1.77 \pm 0.17 \\
0.67 \pm 0.15\end{array}$ & $\begin{array}{l}96.23 \pm 2.11 \\
95.94 \pm 2.86 \\
95.02 \pm 2.33 \\
97.89 \pm 1.05\end{array}$ \\
\hline 60 & $\begin{array}{c}0.5 \\
1.0 \\
1.5 \\
\text { Control }\end{array}$ & $\begin{array}{l}14.70 \pm 0.65 \\
15.30 \pm 0.65 \\
16.70 \pm 0.87 \\
13.20 \pm 0.88\end{array}$ & $\begin{array}{l}5.43 \pm 1.16 \\
6.33 \pm 1.27 \\
8.11 \pm 1.83 \\
2.11 \pm 0.32\end{array}$ & $\begin{array}{l}1.77 \pm 0.14 \\
1.88 \pm 0.12 \\
1.91 \pm 0.18 \\
1.11 \pm 0.12\end{array}$ & $\begin{array}{l}92.80 \pm 3.40 \\
91.79 \pm 4.96 \\
89.98 \pm 2.16 \\
96.78 \pm 2.06\end{array}$ \\
\hline
\end{tabular}


Table 3 Total survival rate of controland treatmentgroups after the bacterial challenge(mean $\pm \mathrm{SD})$

\begin{tabular}{cc}
\hline Treatment groups & Survival rate (\%) \\
\hline $0.0 \mathrm{gr} / \mathrm{kg}(\mathrm{C})$ & $44.44 \pm 6.11^{\mathrm{a}}$ \\
$0.5 \mathrm{gr} / \mathrm{kg}$ & $84.44 \pm 3.39^{\mathrm{b}}$ \\
$1.0 \mathrm{gr} / \mathrm{kg}$ & $86.66 \pm 3.17^{\mathrm{c}}$ \\
$1.5 \mathrm{gr} / \mathrm{kg}$ & $91.11 \pm 2.23^{\mathrm{d}}$ \\
\hline
\end{tabular}

$\mathrm{C}=$ Control. Varied letters indicate significant differences between groups.

\section{Discussion}

Dietary medicinal plant extracts, like $E$. purpurea extract (EPE), as immunostimulants, elevate non-specific defenses during period stress (Yin, Wiegertjes, Li, Schrama, Verreth, Xu \& Zhou 2004; Cao, Ding, Zhang, Jeney \& Yin 2008). Hematological assay may provide an index of the physiology status of fish. This study indicates the effects of E. purpurea extracton the hematological parameters and immunological responses in rainbow trout $(O$. mykiss). In the present study, the hematological parameters such as WBC and Neutrophil indices were significant differences at the end of identical 30 and 60 days period after feeding when compared to control group. Also these parameters (WBC, Neutrophil) were higher in fishes feed with higher concentration of EPE. These results are in consistent with the results obtained of many researchers who reported common carp treated with dietary $E$. purpurea supplementation were significant differences in WBC and differential leukocytes counts (Gopulakannan \& Arul 2006; Yin, Adro, Thompson, Adams, Jeney \& Jeney 2009). Also, Oskoii, Kohyani, Parseh \& Sadeghi. (2012) showed that EPE increased WBC in rainbow trout.

Serum proteins are various humoral elements of the non-specific immune system, measurable total protein, albumin and globulin levels suggest that high concentrations are likely to be a result of the enhancement of the nonspecific immune response of fish. Globulin is the main resource of immunoglobulin production, thus its enhancement in serum provide immunostimularory potential. Albumin, total immunoglobulin and total protein do not indicate significantly differences in treated group in compare to control group. Similar result was reported in Cyprinus carpio fingerlings of treated levamisole (Maqsood, Samoon \& Singh 2009). In our study, there were no significant differences in total immunoglobulin between experimental and control groups. Similar results were reported in 
tilapia fed with Astragalus membranaceus extract (Ardo, Yin, Xu, Varadi, Szigeti, Jeney \& Jeney 2008). But some herbal planets such as ginger (Dugenci, Arda \& Candan 2003), mint and cinnamon (Hajibeglu \& Sudagar 2010) and Magnifera indica (Rao, Das, Pradhan \& Chakrabarti 2006) increase serum proteins such as albumin and globuline. This could be because of the differences in herbal extract ingredients.

Complements especially $\mathrm{C}_{3}$ are produced by hepatic cells and they are very important in bactericidal effects of mucous and serum (Ellis 2001; Holland \& Lambirs 2002).The results obtained of this study indicated an enhancement in complement $\mathrm{C} 3$ concentration at the end of the experiment. These results are in agreement with the results obtained from other studies. Awad et al. (2010) showed that using the extracts of Lupinus perennis, Managifera indica and Urtica dioica especially at the concentrations of 1 and $2 \%$ in fish diet corroborated the activity of complement ingredients especially $\mathrm{C} 3$ and $\mathrm{C} 4$ in rainbow trout. The same results obtained from the treatment with Radix astragalinseu and $R$. Angelicae sinensis in common carp and yellow croaker (Jian \& Wu 2003, 2004). Furthermore Eclipta albae xtract increased complement ingredients concentration in tilapia (Christy bapita, Divyagnaneswari \& Michael 2007).

Also, the results obtained of this study indicated an enhancement in respiratory burst activity in treated groups in comparison with control group, which are in agreement the results of some of studies with dietary immunostimulants used in various fish species (Peddie \& Secombes 2003; Yin et al., 2009; Bilen \& Bulut 2010). Respiratory burst activity is considered as an important indicator of non-specific defense in fish, which is a measure of the increase of oxidation level in phagocytes stimulated by foreign agents (Liaghat, Akhlaghi, Hosseini, Nematollahi \& Hosseini 2011). Respiratory burst and phagocytosis response by phagocytes in blood present a major antibacterial defense mechanism in fish (Harikrishnan, Balasundaram \& Heo 2010). The main cells involved in phagocytosis in fish are neutrophils and macrophages. These cells remove bacteria mainly by the production of reactive oxygen species (ROS) during a respiratory burst. In addition, neutrophils possess myeloperoxidase in their cytoplasmic granules, which in the presence of halide and hydrogen peroxidase kills bacteria by halogenations of the bacterial cell wall. Moreover, these cells possess lysozymes and other hydrolytic enzymes in their lysosomes (Uribe, Folch, Enriquez \& Moran 2011). Similarly, macrophages can produce nitric oxide in mammals and can be as potent antibacterial agents, peroxynitrates and hydroxyl groups (Secombes 1996).

But, in this study there was no significant difference between treatment groups in lysozyme activity nonetheless there was significant difference between treatment groups and control group. These results are in agreement with several reports indicating the 
role of herbal immunostimulants in enhancing lysozyme activity (Rao et al., 2006; Choi, Park, Yoon, Kim, Jang \& Choe 2008). Lysozyme is a humoral component of the non-specific defense mechanism which has the ability to prevent the growth of bacteria by splitting â-1, 4 glycosidic bonds in the peptidoglycan of bacterial cell walls.

The results of the bacterial challenge experiment have shown a significant difference between treatment groups and control in mortality rate. Other results of this study are shown that the treatment with EPE increased non specific immune system in fish. Lower mortality in treatment groups could be because of treatment with EPE. Other experiments have shown that herbal plantsextract treatment increased the resistance of common carp against $A$. hydrophila (Hajibeglu \& Sudagar 2010). Same results obtained from treatment of tilapia with Psidium guajava extract against A. hydrophila (Pachanawan, Phumkhachorn \& Rattanachaikunsopon 2008).

In conclusion, supplementation of EPE in rainbow trout diet enhances non-specific immune system and it's resistant against $S$. iniae. Also its upper concentrations have better results.

\section{Acknowledgement}

The authors would like to thank the Iranian Fisheries Science Research Institute (IFSRI) for the financialSupport, and $\mathrm{Mr}$.
Fakharzadeh\&Mis. Tahereh Sadat Alavifor serious helps.

\section{References}

Ahmad M.H., El Mesallamy A.M.D., Samir F. and Zshran F. (2011) Effect of cinnamon (Cinnamomum zeylanicum) on growth performance, feed utilization, whole body composition and resistance to Aeromunas hydrophila in Nile tilapia. Journal of Applied Aquaculture 23, 289-298.

Ardo L., Yin G., Xu P., Varadi L., Szigeti G., Jeney Z. and Jeney G. (2008) Chinese herbs (Astragalus membranaceus and Lonicera japonica) and boron enhance the non-specific immune response of Nile tilapia (Oreochromis niloticus) and resistance against Aeromonas hydrophila. Aquaculture 275, 26 - 33.

Austin B. and Austin D.A. (2007) Bacterial fish pathogens, Diseases of farmed and wild fish. Springer.

Awad E. and Austin B. (2010) Use of lupin, Lupinus perennis, mango, Mangifera indica, and stinging nettle, Urtica dioica, as feed additives to prevent Aeromonas hydrophila infection in rainbow trout, Oncorhynchus mykiss (Walbaum).Journal of Fish Diseases 33, 413420. 
Bilen S. and Bulut M. (2010) Effects of Laurel (Laurusnobilis) on the non-specific immune responsesof rainbow trout (Oncorhynchusmykiss, Walbaum). Journal of Animal and Veterinary Advances 9, 1275-1279.

Buller N. B. (2004) Bacteria from fish and other aquatic animals: A practical identification manual. CABI Publishing, Cambridge.

Cao L., Ding W., Zhang L., Jeney G., Yin G. (2008) Effect of the activation of immunological cells in the common carp after stimulation by Lentinan and Astragalus polysaccharides. Journal of Anhui Agricultural University35, 219-223.

Castro S.B.R., Leal C.A.G., Freire F.R., Carvalho D.A., Oliveira D.F. and Figueiredo H.C.P. (2008) Antibacterial activity of plant extracts from Brazil against fish pathogenic bacteria. Brazilian Journal of Microbiology 39(4),756-760.

Choi S.H., Park K.H., Yoon T.J., Kim J.B., Jang Y.S. and Choe C.H. (2008) Dietary Korean misteleto enhances cellular non-specific immune responses and survival of Japanese eel (Anguilla japonica). Fish and Shellfish Immunology 24, 67-73.
Christybapita D., Divyagnaneswari M. and Michael D. (2007) Oral administration of Eclipta alba leaf aqueous extract enhances the non-specific immune responses and disease resistance of Oreochromis mossambicus. Fish and Shellfish Immunology 23, 840-852.

Dahui L., Wang Zaigui W. and Yunhua Z. (2011) Antifungal activity of extracts by supercritical carbon dioxide extraction from roots of Echinacea angustifolia and analysis of their constituents using gas chromatographymass spectrometry (GC-MS). Journal of Medicinal Plants Research 5, 5605-5610.

Dugenci S.K., Arda N., Candan A. (2003) Some medicinal plants as immunostimulant for fish. Journal of Ethnopharmacology 88, 99-106.

Ellis A.E. (1990) Lysozoyme assays. In: techniques in fish immunology (ed. By J.S. stolen, T.C fletcher, D.P. Anderson, B.S.Robertson \& W.B. Vanmuisvinkel), pp. 101-103 . S.O.S Publications, FAIR Haven, NJ, USA.

Ellis A.E. (2001) Innate host defence mechanism of fish against viruses and bacteria. Developmental and Comparative Immunology, 25, 827-839.

Galina J., Yin G., Ardo L. and Jeney Z. (2009) The Use of Immunostimulating herbs in fish. An 
overview of research, Fish Physiology and Biochemistry, 35,669- 676 .

Gopalakannan A and Arul V. (2006) Immunomodulatory effects of dietary intake of chitin, chitosan and levamisole on the immune system of Cyprinus carpio and control of Aeromonas hydrophila infection in ponds. Aquaculture 255, 179-187.

Hajibeglu A. and Sudagar M. (2010) Immune response of common carp (Cyprinus carpio) fed with herbal immunostimulants diets. Journal of Animal and Veterinary Advances 9(13), 18391897.

Harikrishnan R., Balasundaram C. and Heo M.S. (2010) Herbal supplementation diets on hematology and innate immunity in goldfish against Aeromonas hydrophila. Shellfish Immunology 28, 354-361.

Holland M.C.H. and Lambris J.D. (2002) The complement system in teleosts. Fish and Shellfish Immunology 12, 399-420.

Ivanova N.T. (1983) Atlas of Fish Blood Cells. LPP Mosacow, Russia (In Russian).

Jian J. and Wu Z. (2003) Effects of traditional Chinese medicine on nonspecific immunity and disease resistance of large yellow croaker, Pseudosciaena crocea (Richardson). Aquaculture 218, 1-9.
Jian J. and Wu Z. (2004) Influence of traditional Chinese medicine on non specific immunity of Jian Carp (Cyprinuscarpio var. Jian). Fish and Shellfish Immunology 16, 185-191.

Johnson A.M., Rohlfs E.M.and Silverman L.M. (1999) Textbook of clinical chemistry In: Tietztextbook of clinical chemistry (ed. by C.A.Burtis, E.K.Ashwood), pp.12-507. Philadelphia: W.B. Saunders company.

Liaghat M., Akhlaghi M., Hosseini A., Nematollahi A. and Hosseini S.M. (2011) Humoral and nonspecific immune responses in rainbow trout (Oncorhynchus mykiss) naturally exposed to and immunized with Streptococcus iniae. International Journal of Veterinary Research 5, 218-224.

Maqsood S., Samoon M.H. and Singh P. (2009) Immunostimulatory and growth promoting effect of dietary levamisole in Cyprinus carpio fingerlings against the challenge of Aeromonas hydrophila. Turkish Journal of Fisheries and Aquatic Sciences9, 111-120.

Maqsood S., Singh P., Samoon M.H. and Munir K. (2011) Emerging role of immunostimulants in combating the disease outbreak in 
aquaculture. International Aquatic Research 3, 147-163.

Mathews E.S., Warinner J.E. and Weeks B.A. (1990) Assay of immune function in fish macrophages. In: Techniques in Fish Immunology (ed. by J.S. Stolen, T.C. Fletcher, D.P.Anderson, B.S.Roberson, W.B. van Muiswinkel), pp. 155-163. SOS publications.

Melchart D., Walther E., Linde K., Brandmier R. and Lersch C. (1998) Echinacea Root Extracts for the prevention of upper Respiratory Tract infections. American Medical Association $7,541-545$.

Morrazoni P., Cristoni A., Di Pierro F., Avanzini C., Ravarino D., Stornello S., Zucca M. and Musso T. (2005) In vitro and in vivo immune stimulating effects of a new standardized Echinacea angustifolia root extract (Polinacea). Fitoterapia 76 , 401- 411.

Oskoii S.B., Kohyani A.T., Parseh A., Salati A.P. andSadeghi E. (2012) Effects of dietary administration of Echinacea purpurea on growth indices and biochemical and hematological indices in rainbow trout (Oncorhynchus mykiss) fingerlings. Fish Physiology and Biochemistry 38(4), 1029-34.

Pachanawan A., Phumkhachorn P.and Rattanachaikunsopon P. (2008) Potential of Psidium guajava supplemented fish diets in controlling Aeromonas hydrophila infection in tilapia (Oreochromis niloticus). Journal of Bioscience and Bioengineering 106, 419-24.

Peddie S. and Secombes C.J. (2003) The Immunostimulatory effects of Chevimmun in the rainbow trout (Oncorhynchus mykiss). European Association of Fish Pathologists 23, $48-51$.

Rao Y.V., Das B.K., Pradhan J. and Chakrabarti R. (2006) Effect of Achyranthes aspera on the immunity and survival of Labeo rohita infected with Aeromonas hydrophila. Fish and Shellfish Immunology 20, 263-273.

Rodas B.A., Angulo J.O., Cruz J. and Garcia H.S. (2002) Preparation of probiotic butter milk with Lactobacillus reuteri. Milchwissenschoff Milk Science International 57, 26-28.

Secombes C.J. (1996) The non-specific immune system: cellular defenses. In: The fish immune system: organism, pathogens and environment (ed. by G.Iwama, T. Nakanishi), pp. 63-103. CA Academic Press San Diago.

Shahsavani D., Mohri M. and GholipourKanani H.( 2010) Determination of normal values of some blood serum enzymes in Acipenser stellatus Pallas. Fish Physiology and Biochemistry 36, 39-43.

Soudi S., Hashemi S.M., ZavaranHosseini A., Ghaemi A. and AsghariJafarabadi M. 
(2007)Anti leishmanial Effect of Echinaceae purpurea root extract cultivated in Iran, Iranian Journal of Pharmaceutical Research 6(2), 147 149.

Stimpel M., Proksch A., WagnerH.and Lohman M.L. (1984) Macrophage activation an induction of macrophage cytotoxicity by purified polysaccharide fraction from the plant Echinacea purpurea. Infection and Immunity 46, 845-849.

Subeena Begum S. and Navaraj P.S (2012) Synergistic effect of plant extract supplemented diets on immunity and resistance to Aeromonas hydrophila in Mystus. IOSR Journal of Pharmacy and Biological Sciences 2(4), 30-36.

Uribe C., Folch H., Enriquez R. and Moran G. (2011) Innate and adaptive immunity in teleost fish: A review. Veterinarni Medicina 10, 486503.

Whicher J. (1996) Complement Component. In: Serum proteins in clinical medicine (ed. by R.F. Richie, O. Novolotskaia), pp. 17.Foundation for Blood Research, Scarborough.

Xu D.J., Xia Q., Wang J.J., Wang P.P. (2008) Molecular Weight and Monosaccharide Composition of Astragalus polysaccharides. Molecules 13, 2408-2415.

Yin G., Wiegertjes G., Li Y., Schrama J., Verreth J., Xu P. and Zhou H. (2004) Effect of Astragalus radix on proliferation and nitric oxide production of head kidney macrophages in Cyprinus carpio: an in vitro study. Journal of Fisheries of China28, 628-632.

Yin G., Adro K.D., Thompson A., Adams A., Jeney Z. and Jeney G. (2009) Chinese herbs (Astragalus radix and Gonoderma lucidum) enhance immune response of carp, Cyprinuscarpio and protection against Aeromonas hydrophila. Fish and Shellfish Immunology26,140-145. 
بررسى اثر عصاره سرخاركل (Echinacea purpurea) بر آيمنى غير

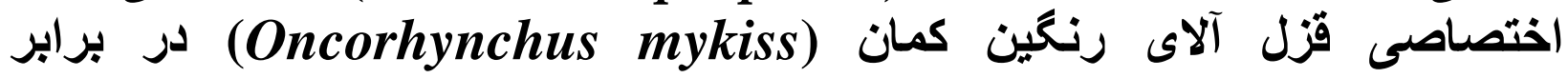
Streptococcosis استريتوكوكوزيسن

مصطفى شريف روحانى "1, رضايور غلام²,مسعود حقيقى 3

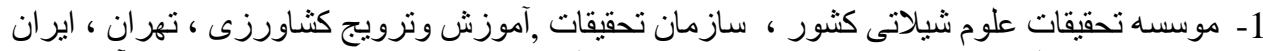

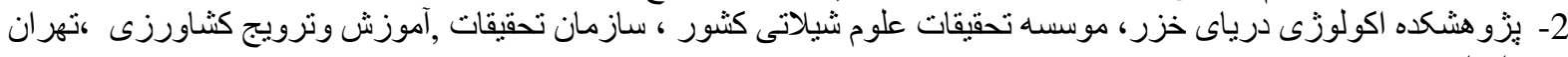

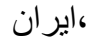

3- مركز تحقيقات ماهيان سردابى تنكابن، موسسه تحقيقات علوم شيلاتى كثور، سازمان تحقيقات ,آموزش وترويج كثاورزى ،تهران (ايران

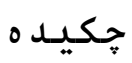

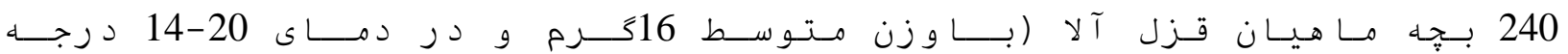

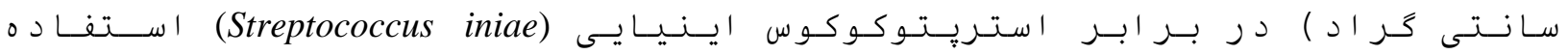

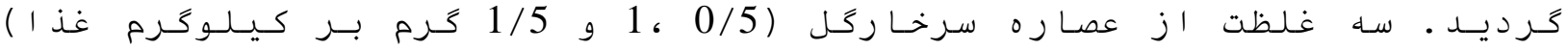

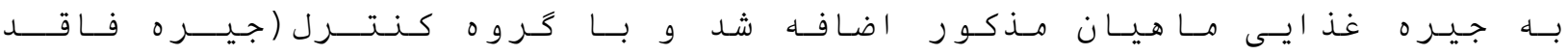

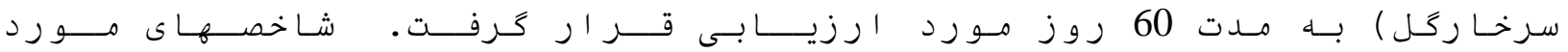

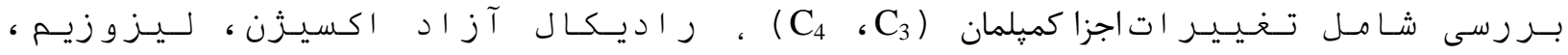

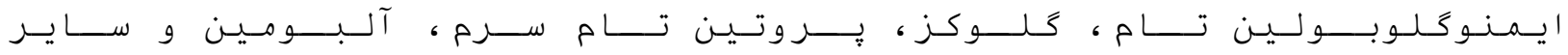

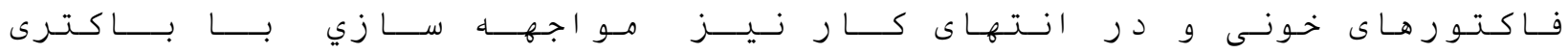

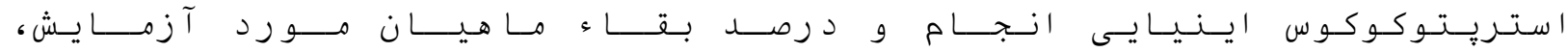

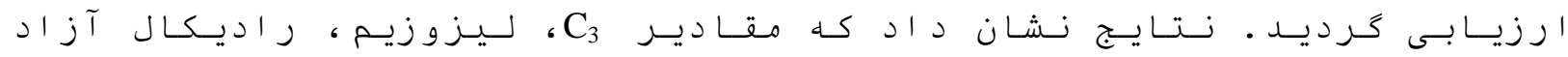

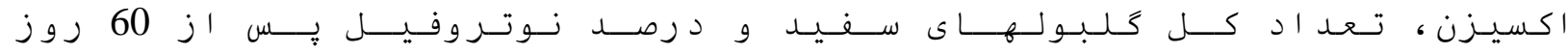

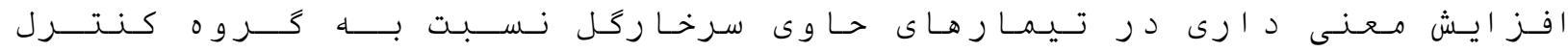

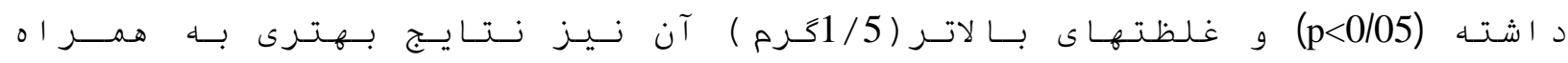

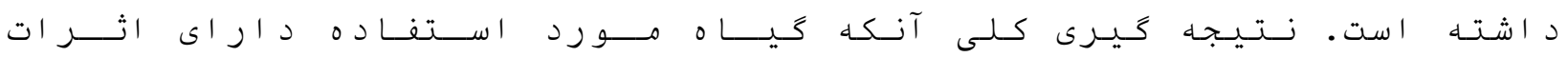

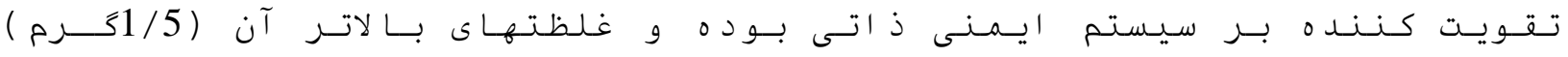

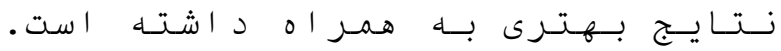

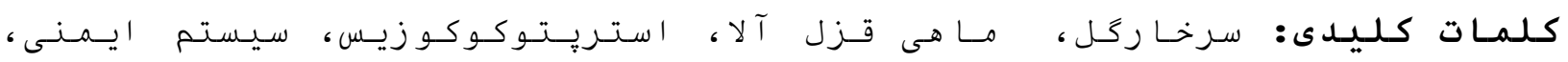

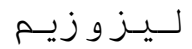
paria.akbary@gmail.com : نويسنده sسئول 